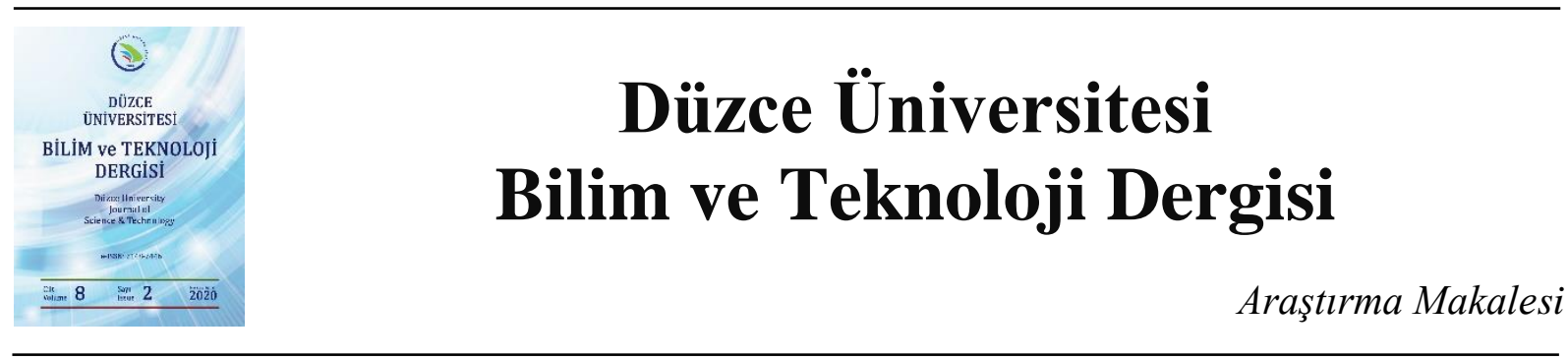

\section{N-Nitrozo-N-Etilüre’nin Zebra Balığı (Danio rerio) Testis Histolojisi Üzerindeki Etkisi}

\author{
(D)Meltem YILMAZ ${ }^{\mathrm{a}, *}$, (DCansu AKBULUT ${ }^{\mathrm{a}}$, (D) Nazan Deniz YÖN ERTUĞ ${ }^{\mathrm{a}}$ \\ ${ }^{a}$ Biyoloji Bölümü, Fen Edebiyat Fakültesi, Sakarya Üniversitesi, Sakarya, TÜRKIYYE \\ * Sorumlu yazarın e-posta adresi: yilmazmeltem17@gmail.com \\ DOI : 10.29130/dubited.658364
}

\begin{abstract}
ÖZET
N-Nitrozo bileşikleri, 20. yüzyılın başından itibaren bilinen, ancak 1950'lerden sonra canlı sağllğ üzerine etkileri daha çok dikkat çeken bileşiklerdir. N-Nitrozo-N-Etilüre (ENU) günümüzde gıda ürünlerini koruyarak raf ömrünü uzatmada kullanılan N-Nitrozo çeşitlerindendir. Deney hayvanları üzerinde yapılan araştırmalar sonucunda toksik, teratojenik, mutajenik ve kanserojenik etkilerinin olduğu ortaya konmuştur. Bu çalışmada ENU maddesi uygulanan, erkek zebra balıklarının testis dokusunda meydana gelen değişimler histopatolojik olarak araştırılmıştır. Çalışma için bir kontrol ve dört deney grubu olmak üzere toplam beş grup oluşturulmuştur. Deney grubundaki akvaryumlara, 0,25 mM, 0,50 mM konsantrasyonlarda birer ve ikişer saatlik ENU uygulanmış olup 6. gün sonunda diseksiyon yapılmıştır. Alınan zebra balığı testis dokusuna rutin histolojik işlemler uygulanmıştır. Konsantrasyon ve uygulama süresinin artışına bağlı olarak deney gruplarının testis dokusunda, seminifer tübüllerde yapısal bozulmalar, vakuolizasyon, spermatogenik seriye ait hücre kümelerinde konsantrasyona bağlı olarak azalma, bazı hücrelerde hipertrofi ve bağ dokusunda dejenerasyonlar tespit edilmiştir. Histolojik incelemeler neticesinde ENU'ya maruz kalan erkek zebra balıklarının testis dokularında olumsuz değişimler belirlenmiştir.
\end{abstract}

Anahtar Kelimeler: Zebra balı̆̆g, N-Nitrozo-N-Etilüre (ENU), Testis, Histopatoloji.

\section{Investigation of The Effect of N-Nitrozo-N-Ethylure On Zebrafish (Danio rerio) Testicular Histology \\ ABSTRACT}

N-Nitrozo compounds are known from the beginning of the 20th century, but after 1950s their effects on living health were more prominent. N-Nitrozo-N-Ethylurea (ENU) is one of the N-Nitrozo varieties used today to protect food products and extend shelf life. As a result of research on experimental animals, toxic, teratogenic, mutagenic and carcinogenic effects have been revealed. In this study, changes in testicular tissue of male zebrafish treated with ENU were investigated histopathologically. A total of five groups, one control and four experimental groups, were formed for the study. ENU was applied to the aquaria in the experimental groups at concentrations of $0.25 \mathrm{mM}$ and $0.50 \mathrm{mM}$. Routine histological procedures were applied to the zebrafish testis tissue. Due to the increase in concentration and application time, structural disruptions in seminiferous tubules, vacuolization, decrease in cell clusters, hypertrophy in some cells, degenerations in connective tissue were detected in testicular tissue of the experimental groups. Histological examinations revealed negative changes in testicular tissues of male zebrafish exposed to ENU.

Keywords: Zebrafish, N-Nitrozo- N-Ethylurea (ENU), Testis, Histopathology. 


\section{GIRIS}

Her geçen gün artan insan nüfusu, endüstrinin hızlı gelişimi sebebiyle endüstriyel kaynaklı kirleticiler doğaya karışmakta [1] ve kirlilik sucul ekosisteme ulaşmaktadır [2]. Sucul ekosistemlerde ise bu kirliliğe en çok balıklar maruz kalmaktadır [3]. Endüstriyel atık bölgelerinde, kimyasal depo alanlarında toksik maddeler meydana gelebilir. Balıklar, bu toksik maddelerin yer altı ve yer üstü sularda meydana getirdiği etkileri, kirlenmenin tespit edilmesinde ve izlenmesinde kullanıma en uygun olan omurgalı canlılardır [4].

Son y1llarda yapılan çalışmalarda, zebra balığ 1 insan hastalıkları için gelişme ve organogenezi de içine almakla birlikte, biyolojik sorunların araştırılıp incelenmesi için önemli bir canlı sistem olarak yerini almıştır [5]. Zebra balığının, bütünleştirici fizyoloji ve ekotoksikoloji veya su ürünleri yetiştiriciliği gibi uygulamalı araştırma alanlarının da kullanımı artarak devam etmektedir [6].

N-Nitrozo-N-Etilüre'nin (ENU) doğada kendiliğinden oluştuğu bilinmemektedir. İlk olarak 1919'da N-Etilüre, nitröz asit reaksiyonu ile Werner ortaya koymuştur [7]. ENU (N- Nitrozo N-Etilüre) birçok canlı türünde kanserojen olan ve böylece DNA'ya hasar vererek hücre ölümüne yol açan bir kimyasal ajandır. Deney hayvanları üzerinde yapılan araştırmalar neticesinde toksik, teratojenik, mutajenik ve kanserojenik etkilerinin olduğu belirtilmiştir. N-Nitrozo bileşiklerinin öncü maddeleri olan nitrat ve nitrit ise sularda ve toprakta önemli miktarda bulunmaktadır. Nitrat ve nitritin sodyum ve potasyum tuzları, günümüzde, yiyeceklerden içeceklere, havuzlardan şampuanlara, kuru temizleme ürünlerinden pestisitlere ve kozmetik ürünlerine kadar geniş bir alanda; mikrobiyal dayanıklılık oluşturma, koruma, olgunlaştırma, raf ömrünü uzatma, kürleme amacıyla sıklıkla kullanılmaktadır [8].

$\mathrm{Bu}$ çalışmada N-Nitrozo-N-Etilüre uygulanan erkek zebra balığı testis dokusunda meydana gelebilecek histopatolojik değişimlerin araştırılması amaçlanmıştır.

\section{MATERYAL VE METOD}

\section{A. ZEBRA BALIĞI}

Zebra balıklarının, dayanıklı bir tür olmalarının yanı sıra kolay temin edilmesi, ucuz olması, hızlı gelişimi ve laboratuvar koşullarında kolay beslenmesi nedeniyle [9] model olarak çalışılmıştır. Araştırmamızda Sakarya Üniversitesi Fen Edebiyat Fakültesi Biyoloji Bölümü, Balık Yetiştirme

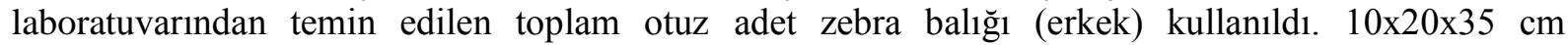
boyutlarında 5 adet akvaryum temin edildi. Akvaryumlardaki suyun sıcaklığı $25 \pm 1^{\circ} \mathrm{C}$ olacak şekilde sabitlendi ve sürekli hava motorları ile oksijenlendirildi.

\section{B. ENU MARUZIYETI}

Deney kapsamında bir kontrol ve dört deney grubu olmak üzere toplam beş grup oluşturuldu. Her grupta altışar erkek zebra balığı olmak üzere toplamda otuz erkek zebra balığ kullanıldı. Kontrol grubuna hiçbir uygulama yapılmazken, deneme gruplarına $0,25 \mathrm{mM}, 0,50 \mathrm{mM}$ konsantrasyonlarda bir ve ikişer saat süreyle 6 gün boyunca ENU'ya maruz bırakıldı.

\section{HISTOLOJIKK İNCELEME}

ENU' ya maruz bırakılan balıklara 6.günün sonunda diseksiyon işlemi uygulandı. Balıkların anestezisi yaklaşık $15 \mathrm{dk}$. buzlu su içerisinde bekletilerek yapıldı. Dokular 24 saat Bouin fiksatifinde tespit edildi. Dehidrasyon, artan etanol serisinde gerçekleştirildi. Dokular ksilen içinde alkolden arındırıldıktan sonra, parafin içine gömüldü. Mikrotomda $5 \mu \mathrm{m}$ kalınlıkta kesitler alındı. Kontrol ve 
deneme gruplarından alınan testis dokuları Hemotoksilen-Eozin (H\&E) ile boyanarak ışık mikroskobu ile incelendi.

\section{BULGULAR}

Kontrol grubunda normal testis histolojik yapısı gözlendi. Seminifer tübüllerin etrafında bağ doku hücreleri gözlendi. Ișı mikroskobuyla incelenen testis dokusunda, spermatogenik seriye ait hücre kümeleri görüldü. Spermatogonyum, primer spermatosit, sekonder spermatosit, spermatit ve sperm hücreleri izlendi (Şekil 1).

Spematogenik hücrelerin en büyük boyutuna sahip olan spermatogonyumlar genellikle solgun veziküler yapıda oval şekilli bir nukleusa, farklı yapıda nükleer membrana, granüler sitoplazma yapısına sahipti. Primer spermatosit evresinde hücre hacminde küçülme izlendi. Spermatogonyuma göre orta büyüklükte bir hücre boyutuna, yoğun bir nukleusa ve belirsiz bir sitoplazmaya sahipti. Sekonder spermatosit aşamasında büyük nukleuslu hücre hacminin primer spermatosite oranla küçüldüğü gözlendi. Spermatit aşamasındaki hücre boyutu spermatositlere oranla belirgin düzeyde küçüldüğ̈ izlendi. Spermlerin seminifer tübül içinde merkezi kısımda toplandıkları görüldü. $\mathrm{Bu}$ hücrelerin koyu, yuvarlak nukleuslu olduğu ve sitoplazmalarının seçilemediği tespit edildi.

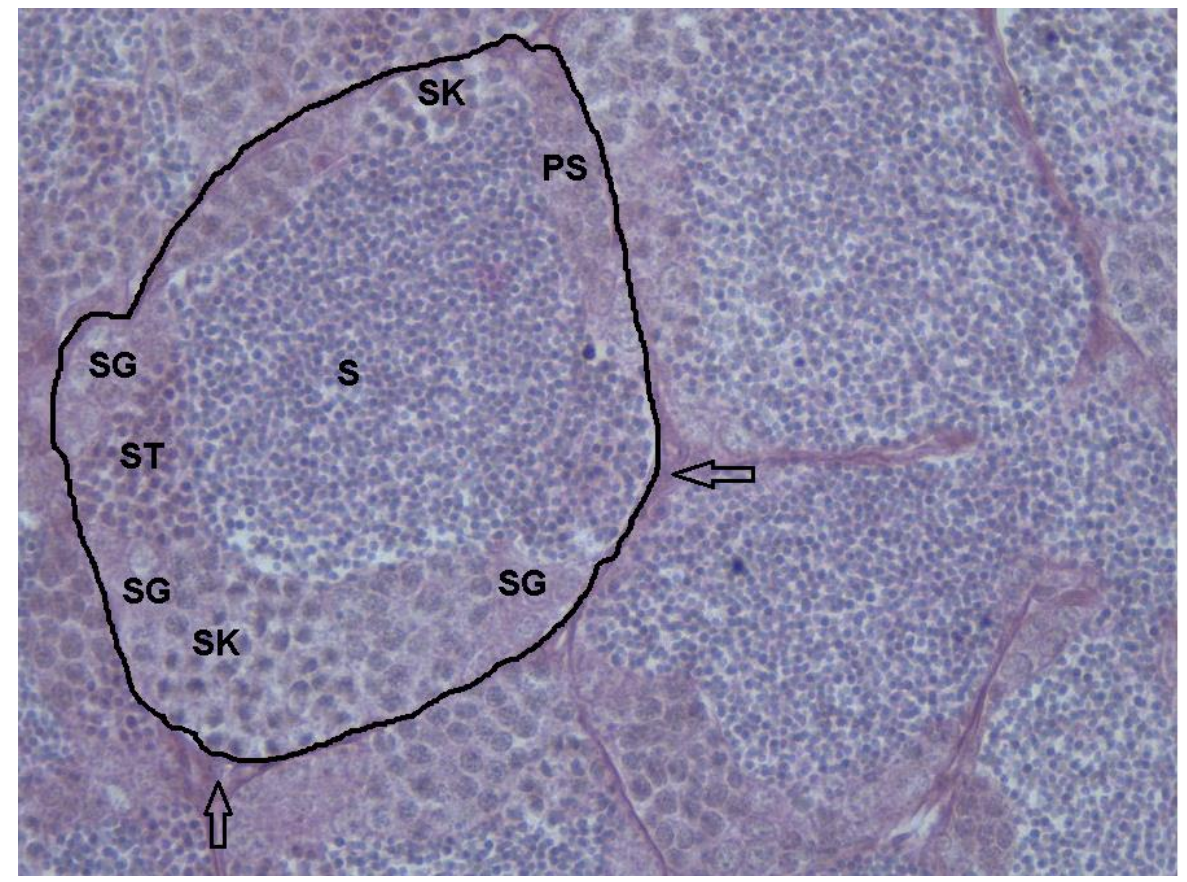

Şekil 1. Kontrol grubu testis genel yaplsindaki seminifer tübül. Sperm (S), Spermatogonyum (SG), Primer spermatosit (PS), Spermatit (ST), Sekonder spermatosit (SK), intersitisyel hücreler (ok), H\&E X40

Yapılan araştırmada ENU uygulanan zebra balığı testis dokusunun histolojik yapısında olumsuz değişimler gösterdiği tespit edilmiştir. Kontrol grubu ve $0,25 \mathrm{mM} 1$ saatlik ENU uygulanmış olan deney grubu ile karşılaştırıldığında; genel olarak seminifer tübül şekil bozukluğu gözlenmiştir. Seminifer tübüllerde vakuolizasyon tespit edilmiştir. Spermatogonyum hücrelerinde hipertrofi izlenmiştir. $0,25 \mathrm{mM} 1$ saatlik ENU konsantrasyon grubunda seminifer tübüller bütünlüğünün bozulması, spermatogenik seriye ait hücrelerin sayısında azalma görülmüştür (Şekil 2). 


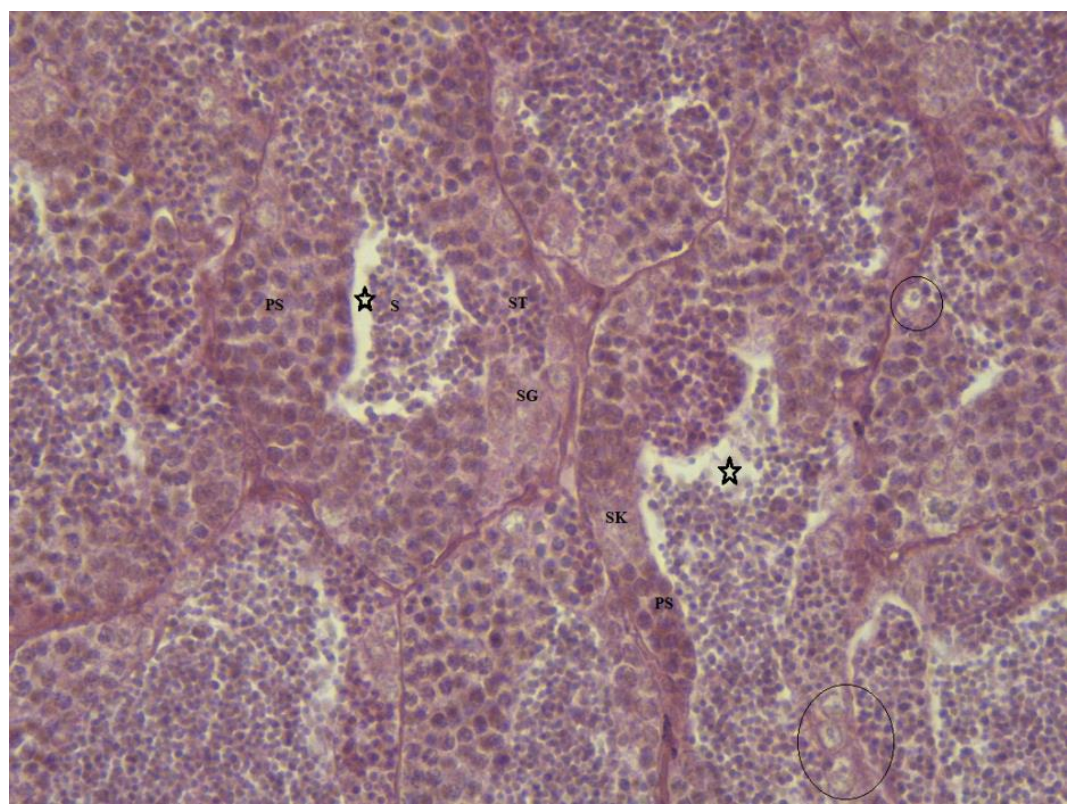

Şekil 2. 0,25 mM 1 saatlik ENU'ya maruz kalan testis dokusu. Seminifer tübül bütünlüğünün bozulması, seminifer tübüllerde vakuolizasyon (ylldı), spermatogonyum hücresinde hipertrofi (çember),sperm (S), spermatogonyum (SG), sekonder spermatosit (SK), spermatit (ST), primer spermatit (PS), H\&E X40

0,25 mM 2 saatlik ENU konsantrasyonu uygulanan grup ile $0,25 \mathrm{mM} 1$ saatlik ENU'ya maruz kalan testis dokusunda benzer histopatolojik etkiler tespit edildi. Ancak tübüllerde meydana gelen dejenerasyon seviyesi, süre artışına bağlı olarak arttığı görüldü. Seminifer tübül sınırları izlenmedi. Spermatogenik seriye ait hücrelerin azaldığı izlendi. Primer spermatosit hücrelerinde hipertrofi tespit edildi (Şekil 3). Ayrıca intersitisyel alanda genişleme, seminifer tübüllerde birleşme ve sperm sayısında artış görüldü (Şekil 4).

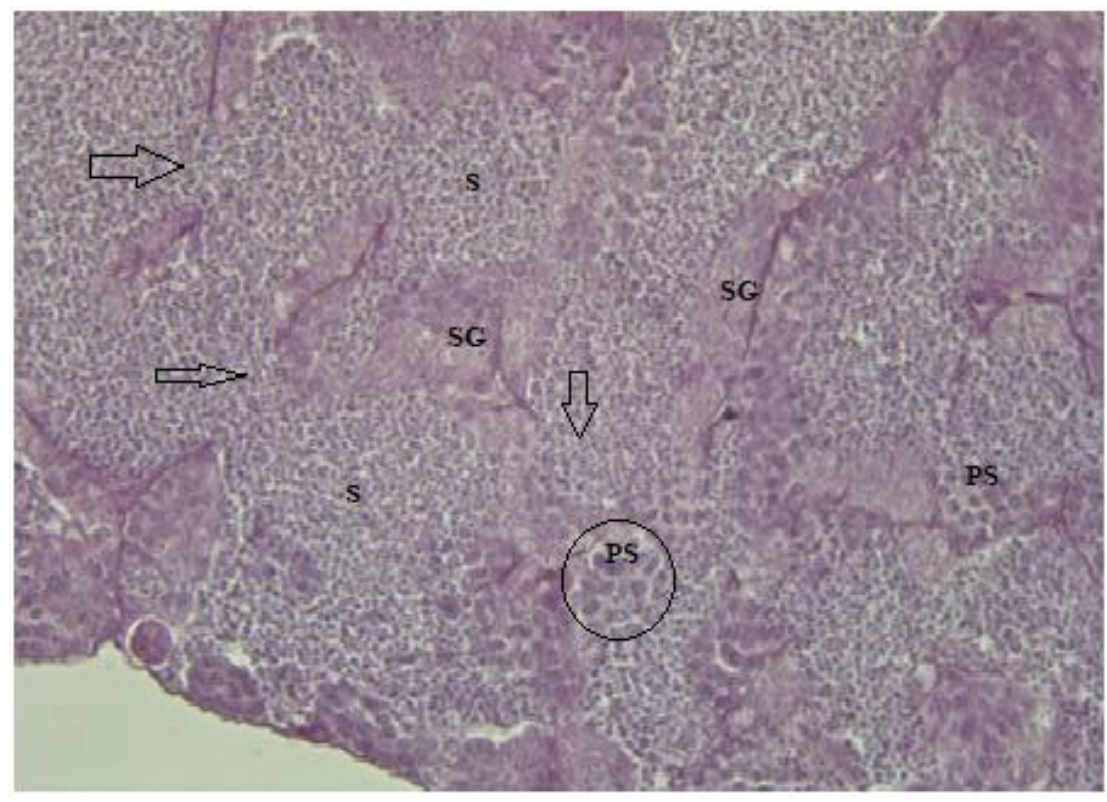

Şekil 3. 0,25 mM 2 saatlik ENU'ya maruz kalan testis dokusu. Seminifer tübül bütünlüğ̈̈n bozulmasl (ok), primer spermatosit hücrelerinde hipertrofi (Çember), primer spermatositler (PS), sperm saylsinda artıs (S), spermatogonyum ( $S G$ ), $H \& E X 40$ 


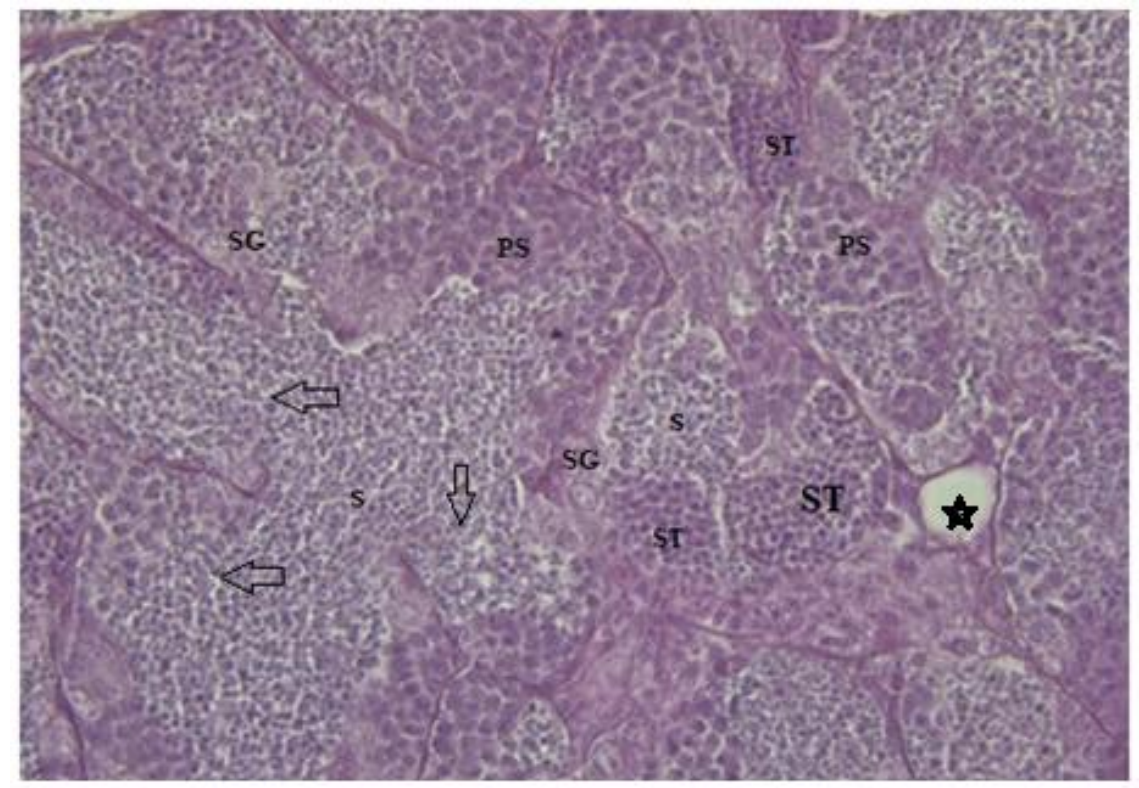

Şekil 4. 0,25 mM 2 saatlik ENU'ya maruz kalan testis dokusu. Seminifer tübüllerde birleşme (ok), intersitisyel alanda genişleme (yıldız), sperm hücresi (S), primer spermatosit(PS), spermatogonyum (SG) spermatit (ST), $H \&$ E Boyama, $X 40$

Kontrol grubu ile $0,25 \mathrm{mM} 1$ ve $0,25 \mathrm{mM} 2$ saatlik ENU'ya maruz kalan testis dokusu konsantrasyon grupları karşılaştırıldığında seminifer tübüllerde yapısal bütünlüğün bozulması daha net görüldü. 0,50 mM 1 saatlik ENU'ya maruz bırakılan grupta, seminifer tübüllerde dejenerasyon, spermatogenik hücre kümelerinin sınırlarında düzensizleşmeler tespit edildi. Spermatogonyum sayılarında azalma olduğu görüldü. İntersitisyel hücrelerde hipertrofi tespit edildi. Seminifer tübüllerde vakuolizasyon izlendi. Spermatogonyum hücresinde hipertrofi görüldü. (Şekil 5).

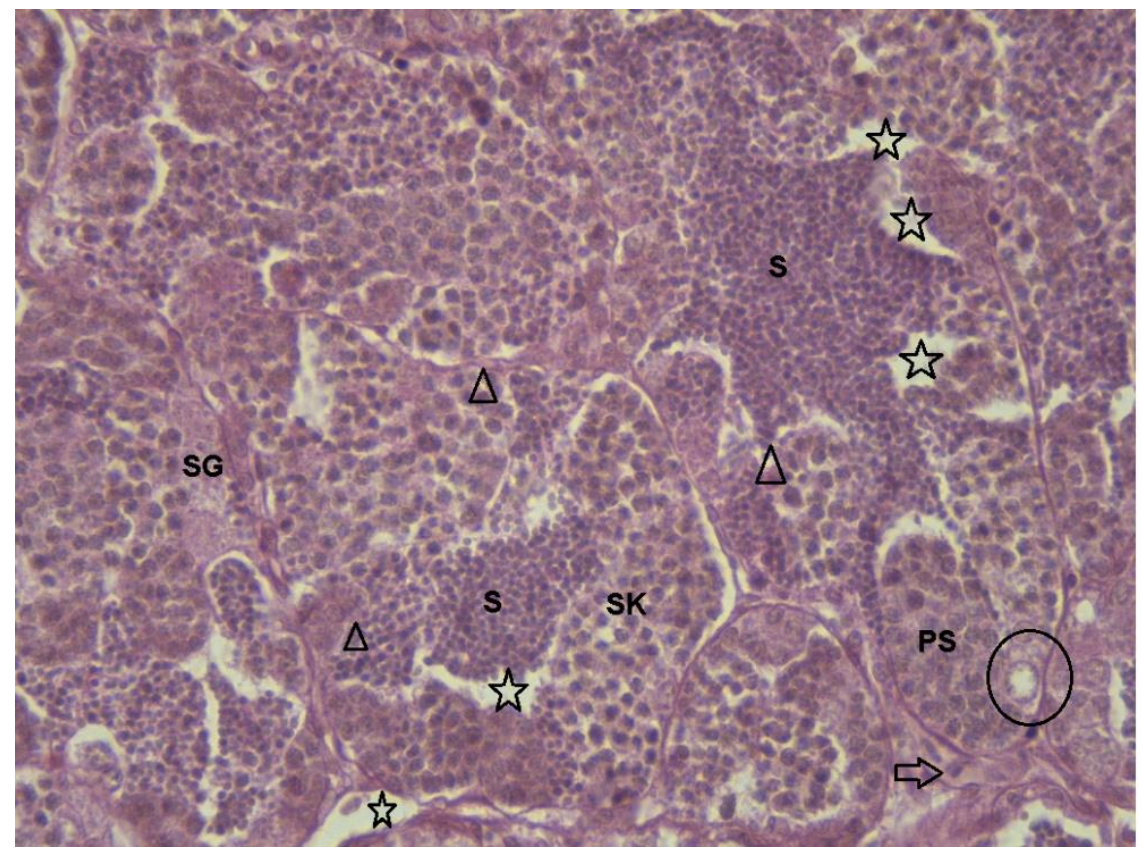

Şekil 5. 0,5mM 1 saatlik ENU'ya maruz kalan testis dokusu. Seminifer tübüllerde vakuolizasyon (yıldız), spermatogenik hücre kümelerinin sinırlarında düzensizleşme (üçgen), spermatogonyum hücresinde hipertrofi (Çember),, intersitisyel hücrelerde hipertrofi (ok) sperm (S), primer spermatit (PS) sekonder spermatosit (SK), spermatogonyum ( $S G), H \& E X 40$ 
$0,50 \mathrm{mM} 2$ saatlik ENU 'ya maruz kalan gruplarda ise seminifer tübüllerde vakuolizasyon ve dejenerasyonların diğer konsantrasyon gruplarına göre daha ileri boyutta olduğu gözlendi. Genel olarak seminifer tübüllerde yapısal dejenerasyon görüldü. Seminifer tübüllerin birleştiği izlendi. Seminifer tübüller içi alanda vakuolizasyon tespit edildi. Bazal laminada yer yer kalınlaşma olduğu izlendi (Şekil 6).

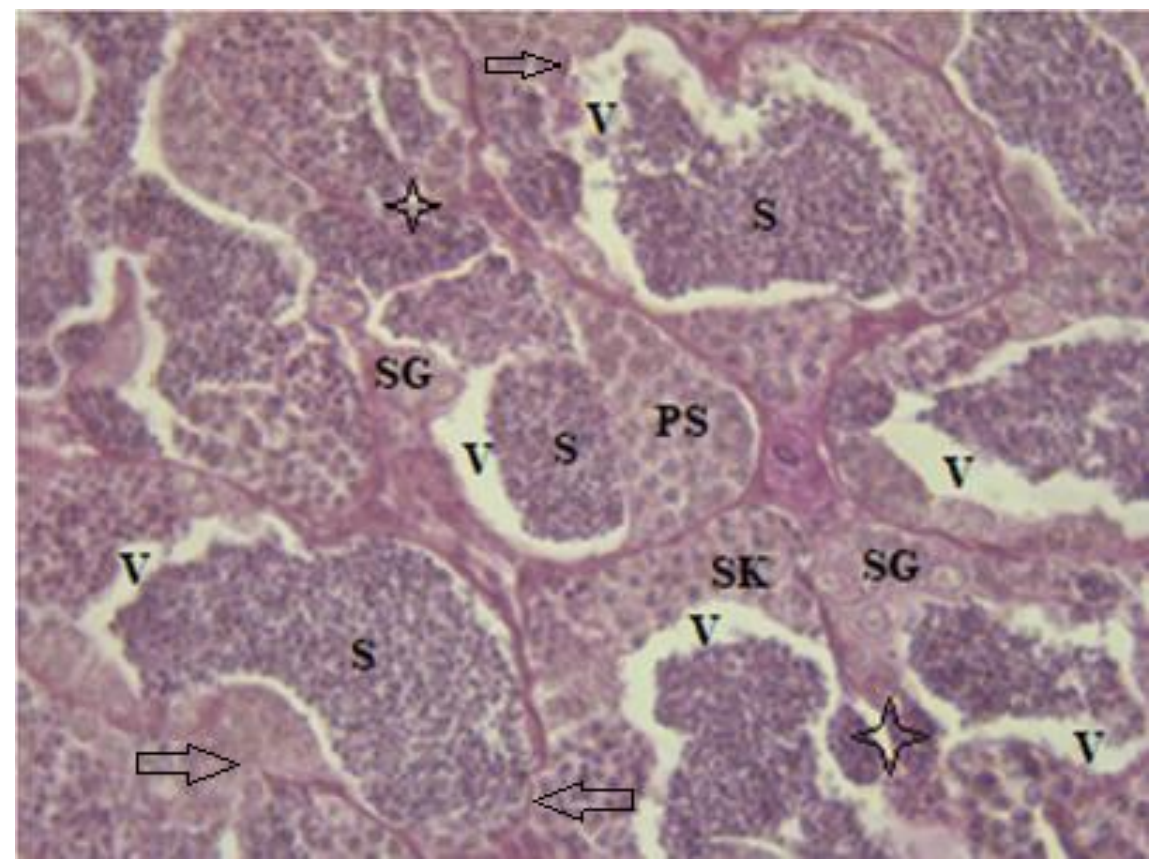

Şekil 6. 0,50 mM 2 saatlik ENU'ya maruz kalan testis dokusu. Seminifer tübüllerde yapısal dejenerasyon (ok), seminifer tübüllerde vakuolizasyon (ylldız), Bazal laminada yer yer kalınlaşma(ok), Sperm (S), Primer spermatit $(P S)$, Spermatit (ST), Spermatogonyum (SG), sekonder spermatosit (SK), H\&E X40

\section{IV.SONUC}

Balıkların üreme potansiyeli ile ilgili yapılan araştırmalarda histolojik incelemeler büyük bir öneme sahiptir. Ayrıca gonadların histolojik yapısının kirliliğe duyarlı olduğu bilinmektedir. Gonadlarda gözlenen yapısal ve histolojik, fizyolojik değişimlerle kirlilik miktarları arasındaki bağlantılar, ortamdaki kirlilik seviyelerinin belirlenmesinde önemlidir [10].

$\mathrm{Bu}$ çalışmada da N-Nitrozo bileşiklerinden biri olan N-Nitrozo-N-Etilüre (ENU) maddesinin zebra balığının testis dokuları üzerindeki histolojik etkileri araştıılmıştır. Yapılan çalışmada, kontrol grubu ile deney grupları karşılaştırılarak iki grup arasında farklılıklar ortaya konmuştur. Buna göre ENU maddesi uygulan zebra balığı testis dokusunda uygulanan konsantrasyon miktarıla orantılı olarak, seminifer tübüllerde dejenerasyon, seminifer tübüllerde vakuolizasyon, spermatogenik seride yer alan hücre kümelerinde yapısal bozulmalar, sınırlarının ve dağılımlarının bozulması, spermatogenik hücre gruplarında vakuolizasyon ve hipertrofi görülmüştür. Ayrıca tübüler arası alanda yer alan bağ dokuda kalınlaşma tespit edilmiştir.

ENU'nun kanserojen etkisinin zebra balığı üzerinde etkisini belirlemek için yapılan bir çalışmada, zebra balıkları $2.5 \mathrm{mM}$ veya $3.0 \mathrm{mM}$ ENU ile maruz bırakılmıştır. Çalışma sonucunda ENU'nun zebra balığında epidermal papillomlar geliştirdiği gözlenmiştir [5].

Jiang ve arkadaşlarının (2011) yaptıkları çalışmada, ENU maddesine maruz bırakılan ot sazanı (Ctenopharyngodon idellus) sperm hücreleri üzerine mutajenik etkisi incelendiğinde, balıkta morfolojik olarak anormal değişikliklerin ve embriyo gelişimi üzerinde baskın etkilerin olduğu 
görülmüştür. Ot sazanlarında ENU maruziyetinin neden olduğu baskın fenotipler, notokord desenleri ve sinir sistemi, iç organ gelişimi gibi spesifik embriyonik gelişim süreçlerinin bozulmasına neden olmuştur. Bunun sebebi olarak da artan ENU veya sentetik öldürücü mutasyonların konsantrasyonu ile doğru orantılı olabileceği düşünülmüştür [11]. Bizim bu çalışmamızda ENU konsantrasyonun artmasıyla testis dokusunda da histolojik deformasyonların daha belirgin olduğu tespit edilmiştir.

Titanyumdioksit $\left(\mathrm{TiO}_{2}\right)$ maddesi kullanarak yapılan bir çalışmada zebra balığına uygulanan konsantrasyon gruplarının artışına bağlı olarak testis dokusunda, spermatagonyum ve spermatosit hücrelerinde azalma, artan konsantrasyonla birlikte seminifer tübüllerde bozulma, parçalanma, düşük konsantrasyonlarla $(1 \mathrm{mg} / \mathrm{L})$ karşılaştırıldığında bu bozulmaların artan düzeyde olduğu tespit edilmiştir. Yüksek konsantrasyona (4 mg/L) maruz kalan dokularda ise spermatogonyum, spermatosit ve spermatik hücrelerin azaldığ görülmüştür [12]. Bu çalışma ile ortaya çıkan sonuçlar bizim çalışmadaki sonuçlar benzerlik göstermektedir.

Deltametrin maddesi uygulanan Xiphophorus helleri testis dokularında meydana gelen histopatolojik etkileri inceleyen bir çalışmada, Xiphophorus helleri 72 saat boyunca $0,02 \mathrm{ppm}$ ve $0,04 \mathrm{ppm}$ konsantrasyonlarında deltametrin maddesine maruz bırakılmıştır. Balıkların testis dokularında kontrol grubuna göre çeşitli bulgulara rastlanmıştır. Konsantrasyon artışına bağlı olarak deney gruplarında sperm hücrelerinde azalma, seminifer tübüllerde dejenerasyon izlenmiştir. Ortaya çıkan sonuçlar bu çalışmadaki sonuçlar ile benzerlik göstermektedir [13].

Lora ve arkadaşlarının (2016) yaptıkları çalışmada, Bisfenol A (BPA) maddesine 14 gün boyunca maruz kalan zebra balığının testislerinde morfolojik değişiklikler meydana gelmiştir. Testis hücre bileşenlerinde belirgin bir dejenerasyon, Sertoli hücrelerin yüzdesinde bir artış ve belirli bir konsantrasyondan sonra $(100 \mu \mathrm{g} / \mathrm{l})$ izlenen üreme hücrelerinin yüzdesinde belirgin bir azalma olduğu tespit edilmiştir [14].

Ham petrolün suda çözünebilen kısımlarının Xiphophorus helleri (Kılıçkuyruk Balığı) testis dokusundaki akut etkilerinin ortaya konduğu bir çalışmada, \%10, \%20, \%40 konsantrasyonlarda ve 24, 48, 72 ve 96 saat süreyle ham petrolün suda çözünebilen kısımlarına, maruz bırakılan kılıçkuyruk balığının, konsantrasyon ve maruziyet süresi artışına paralel olarak tüm deney gruplarının, testis dokusunda yaygın vakuolizasyon, seminifer tübüllerde vakuolizasyon tespit edilmiştir. Bu çalışma ile ortaya çıkan sonuçlar bu çalışmadaki sonuçlar benzerlik göstermektedir [10].

Semicarbazide (SMC) maddesinin zebra balığı üreme sistemi üzerindeki etkilerini inceleyen bir çalışmada, zebra balıklarına 28 gün boyunca 4 konsantrasyon grup şeklinde $(1,10,100$ ve $1000 \mathrm{~g} / \mathrm{L})$ SMC' ye maruz bırakılmıştır. $10 \mathrm{~g} / \mathrm{L}$ ' ye eşit veya daha küçük konsantrasyonlarda SMC'ye maruz kalan balıklarda, kontrol grubuna kıyasla farklılıklar tespit edilmemiştir. Ancak $100 \mathrm{~g} / \mathrm{L}$ konsantrasyon grubunda, yoğun şekilde paketlenmiş spermler, seminifer tübüllerde birçok boşluk gözlemlenmiştir. $1000 \mathrm{~g} / \mathrm{L}$ SMC' ye maruz kalan balıklarda ise spermatositlerin düzensiz, kırık bir tunika propriyası ve daha az spermle birlikte ciddi şekilde dejenere olmuş bir testis dokusu tespit edilmiştir. Artan konsantrasyonlarla birlikte testis dokuda meydana gelen doku harabiyetleri, bu çalışmadaki artan konsantrasyon oranıyla benzer sonuçlar göstermektedir [15].

Sonuç olarak; farklı kimyasal maddelerin testis dokusu üzerinde histopatolojik yönden olumsuz etkilediğini, konsantrasyon artışlarına bağlı olarak bu olumsuz bulguların dokuda daha belirgin olduğu tespit edilmiştir.

\section{KAYNAKLAR}

[1] T. Şişman and F. Geyikoğlu, "PCB 126'ya maruz kalmış zebra balığı (Danio rerio) larvalarındaki sensorimotor hasarlar," Tübav Bilim, vol. 3, no. 1, pp. 61-66, 2010. 
[2] A. Glaser, (20-Nov-2019). "Threatened waters turning the tide on pesticide contamination," Beyond Pesticides, 2006.2 Anline]. Available: https://www.beyondpesticides.org/assets/media/documents/documents/water.pdf

[3] H. M. Dutta and R. Dalal, "The effect of endosulfan on the ovary of bluegill sunfish: a histopathological study (Lepomis macrochirus)," Int. J. Environ. Res, vol. 2, no. 3, pp. 215224, 2008.

[4] R. Nagel, "DarT: the embryo test with the zebrafish Danio rerio - a general model in ecotoxicology and toxicology.," ALTEX, vol. 19 Suppl 1, pp. 38-48, 2002.

[5] L. G. Beckwith, J. L. Moore, G. S. Tsao-Wu, J. C. Harshbarger, and K. C. Cheng, "Ethylnitrosourea induces neoplasia in zebrafish (Danio rerio)," Lab. Investig., vol. 80, no. 3, pp. 379-385, 2000.

[6] M. C. Leal et al., "Histological and stereological evaluation of zebrafish (Danio rerio) spermatogenesis with an emphasis on spermatogonial generations1," Biol. Reprod., vol. 81, no. 1, pp. 177-187, 2009.

[7] E. W. Knapik, "ENU mutagenesis in zebrafish - from genes to complex diseases," Mamm. Genome, vol. 11, no. 7, pp. 511-519, 2000.

[8] Ö. Çakmak, A. İşleyen, ve A. Usca, "N-nitrozo bileşikleri ve halk sağlığına etkileri," TAF Prev. Med. Bull., vol. 8, no. 6, pp. 521-526, 2009.

[9] D. T. Gilmour, J. R. Jessen, and S. Lin, "Manipulating gene expression in the zebrafish," in Zebrafish: A Practical Approach, 1st ed., R. Dahm and C. Nüsslein-Volhard, Eds. Oxford: Oxford University Press, 2002, pp. 121-43.

[10] Ö. Önen ve S. İ. Üçüncü, "Ham petrolün suda çözünebilen kısımlarının Xiphophorus helleri heckel, 1848 ( Poeciliidae, Teleostei ) testis histolojisi üzerindeki etkileri," Kafkas Üniversitesi Fen Bilim. Enstitüsü Derg., vol. 8, no. 1, pp. 59-68, 2015.

[11] X.-Y. Jiang, C.-F. Sun, Q.-G. Zhang, and S.-M. Zou, "ENU-induced mutagenesis in grass carp (Ctenopharyngodon idellus) by treating mature sperm," PLoS One, vol. 6, no. 10, p. e26475, Oct. 2011.

[12] C. Akbulut and N. D. Yön, "Histopathology and cellular apoptosis at spermatogenic cells of zebrafish ( Danio rerio ) at acute and sub-chronic exposure of titanium dioxide $\left(\mathrm{TiO}_{2}\right)$ nanoparticles," Fresenius Environ. Bull., vol. 25, no. January, pp. 2991-2997, 2016.

[13] N. D. Yön, C. Akbulut, F. E. Kayhan, and G. Kaymak, "Histopathological changes in testis of the swordtail fish, Xiphophorus helleri (Pisces: Poecilidae) exposed to deltamethrin," Fresenius Environ. Bull., vol. 21, no. 10, pp. 2866-2870, 2012.

[14] A. J. Lora, A. M. Molina, C. Bellido, A. Blanco, J. G. Monterde, and M. R. Moyano, "Adverse effects of bisphenol a on the testicular parenchyma of zebrafish revealed using histomorphological methods," vol. 2016, no. 10, pp. 577-589, 2016.

[15] M. Yu et al., "Semicarbazide disturbs the reproductive system of male zebrafish ( Danio rerio ) through the GABAergic system," Reprod. Toxicol., vol. 73, pp. 149-157, 2017. 